\title{
Dignidade Indígena, Multiculturalismo e a Nova Hermenêutica Constitucional
}

\author{
Indigenous Dignity, Multiculturalism and the New Constitutional \\ Hermeneutics
}

\section{JULIANNE HOLDER DA CÂMARA SILVA FEIJÓ}

Graduada pela Universidade Federal do Rio Grande do Norte (UFRN), Discente do Curso de Mestrado em Direito Constitucional da UFRN, Bolsista do Programa de Formação de Recursos Humanos em Direito do Petróleo e Gás Natural (PRH 36/ANP).

\begin{abstract}
MARIA DOS REMÉDIOS FONTES SILVA
Graduada em Direito pela Faculdade de Ciências Jurídicas e Sociais - IPE (João Pessoa/PB, 1977), Mestrado em Direitos Humanos pela Université Catholique de Lyon - Institute de Droits de Lhomme (França, 1991), Doutorado em Direitos Humanos - Université Catholique de Lyon - Institute de Droits de Lhomme (França, 1993), Pós-Doutorado pela Université Lumière Lyon II (França, 2007). Atualmente, é Professor Associado II da Universidade Federal do Rio Grande do Norte e Coordenadora do Programa de Pós-Graduação em Direito da UFRN. Tem experiência na área de Direitos Especiais, com ênfase em Direitos Humanos, atuando principalmente com as temáticas: direito ambiental, cidadania, filosofia do direito, sociologia jurídica, ética profissional e metodologia da investigação científica.
\end{abstract}

Submissão: 28.07.2011

Parecer 1: 10.10 .2011

Parecer 2: 14.10 .2011

Decisão Editorial: 14.10.2011

RESUMO: Com a superação do Estado de Direito e a ascensão do Estado Constitucional, novos valores, como o pluralismo e a diversidade cultural, ganharam espaço e relevo político, influenciando as diretrizes das novas constituições que surgiam. Conduziram não só à quebra dos sólidos paradigmas da Era Liberal como imiscuíram os seus valores na definição da nova geração cultural que nascia. Neste contexto, as minorias étnicas ganharam voz e visibilidade política, obtendo o reconhecimento de sua singularidade cultural além do direito a perpetuá-la, pois agora a dignidade humana significa dignidade para todos, o que representa 0 reconhecimento da diversidade e 0 direito à diferença. Trabalhamos, então, a dignidade humana com um valor plástico, que se flexiona e se acomoda aos diferentes contextos sociais e diferentes compreensões do que seja uma vida digna, reflexo da heterogeneidade da sociedade hodierna, principalmente em países de vasta formação étnica e cultural, como os latino-americanos e o seu grande contingente de etnias indígenas e outras comunidades tradicionais. Em seguida, analisamos o papel da jurisdição constitucional na defesa dos direitos fundamentais dessas minorias étnicas, sugerindo que, em face de controvérsias de difícil solução, deveria o Judiciário se valer das técnicas da nova hermenêutica constitucional, tal como a 
teoria material da Constituição e a formação de um bloco de normas constitucionais não inscritas no texto da Carta, bem como dos métodos de exegese propostos por Theodor Viehweg, em sua Tópica e jurisprudência, e por Peter Häberle, em sua $A$ sociedade aberta dos intérpretes da constituição.

PALAVRAS-CHAVE: Pluralismo; dignidade humana; Multiculturalismo; jurisdição constitucional; nova hermenêutica.

ABSTRACT: To overcoming the rule of law and the rise of the Constitution State, new values such as pluralism and cultural diversity gained political prominence and space, influencing the guidelines of the new constitutions that emerged. Led not only sound breaking the paradigms of liberal and was meddling in their values cultural definition of the new generation born. In this context, ethnic minorities gained political voice and visibility, obtaining recognition of their cultural uniqueness and the right to perpetuate it, because now human dignity means dignity for all, which represents the recognition of diversity and the right to difference. Work then the value of human dignity with a plastic, which flexes and accommodates the different social contexts and different understandings of what constitutes a dignified life, reflecting the heterogeneity of today's society, especially in countries with vast cultural and ethnic background as the Latin Americans and their large contingent of indigenous people and other traditional communities. Then we analyze the role of constitutional jurisdiction in the fundamental rights of these ethnic minorities, suggesting that in the face of controversy difficult to solve the judiciary should take advantage of new techniques of constitutional hermeneutics as the theory of material constitution and the formation of a block of constitutional rules not included in the text of the Charter, and the methods of exegesis proposed by Theodor Viehweg in his Topical and Jurisprudence, and Peter Häberle in its open society of interpreters of the constitution.

KEYWORDS: Pluralism; human dignity; Multiculturalism; constitutional jurisdiction; new hermeneutics.

SUMÁRIO: Introdução; 1 Pluralismo, dignidade humana e o significado dos direitos fundamentais; 1.1 Multiculturalismo e proteção à diversidade cultural na América indígena; 2 A nova hermenêutica constitucional e os direitos indígenas; 2.1 Direitos culturais à luz da teoria material da Constituição; 2.20 s intérpretes da dignidade indígena; 30 direito consuetudinário no contexto da jurisdição constitucional; 3.1 As funções estruturante e hermenêutica da jurisdição constitucional em questões indígenas; Conclusões; Referências.

\section{INTRODUÇÃO}

A consolidação do Estado Constitucional inaugurou uma fase humanitária sem precedentes na história da evolução política do homem. Nascido em retaliação à desastrosa experiência nazista que aviltou e abusou dos direitos humanos, o Estado Constitucional coroou a dignidade humana como seu primado nuclear, que se irradiaria pelo sistema jurídico a partir de uma constituição poderosa e invasora. A Carta Magna do Estado Neoconstitucional está em tudo, impregnando com seus valores todos os aspectos da vida social e jurídica, atribuindo o rol de direitos elementares e a materialização de uma vida digna a todas as parcelas da coletividade.

Outra faceta do Neoconstitucionalismo foi reconhecer que a sociedade hodierna é bastante heterogênea e diversificada, composta por uma 
gama de grupos sociais com interesses, aspirações e anseios diferentes que precisam conviver e se harmonizar dentro de um mesmo território nacional e debaixo de uma mesma constituição. O Estado Constitucional, assim, nasceu essencialmente pluralista e multicultural, reconhecendo a diversidade social que encerra e preocupado em dar proteção às minorias nacionais, especialmente em Estados cuja formação étnica e cultural revela inúmeras comunidades tradicionais que vivem em seus costumes próprios, professando religião, línguas e tradições diversos do restante da sociedade envolvente'1.

Assim, a dignidade humana, no contexto do Neoconstitucionalismo, ganha um redimensionamento para compreender o direito à diferença e a proteção à diversidade cultural como um fator inexoravelmente ligado à sua materialização. Indo mais além, se a dignidade humana deve ser garantida aos diferentes grupos que convivem na sociedade plural, compreende-se que ela (a dignidade) se apresenta como um valor plástico e flexível, de modo a se adequar às diferentes realidades dos diferentes segmentos sociais, variando no tempo e no espaço.

Daí que o conteúdo da dignidade humana, assim como dos direitos fundamentais, não pode ser compreendido como algo uniforme, mas variável, transformando-se de realidade para realidade. A uniformidade do conteúdo dos direitos fundamentais nada mais é do que uma construção ocidental, desenvolvida a partir de valores norte-americanos e eurocentristas difundidos por meio do modo de produção capitalista, não correspondendo à realidade dos diversos países latino-americanos e a sua vasta formação étnica e cultural.

Neste viés, aborda-se o multiculturalismo e a proteção à diversidade cultural como direitos fundamentais dos índios, indissociável de sua dignidade humana. Por conseguinte, propõe-se, na solução de delicadas questões envolvendo os interesses indígenas, a utilização de alguns métodos da nova hermenêutica constitucional nascidos no pós-positivismo jurídico, tais como a teoria material da constituição e a formação de um bloco de constitucionalidade dentro do qual estariam os instrumentos internacionais que versam sobre os direitos elementares dessas comunidades, além da uti-

1 A Medida Provisória n² 2.186-16/2001 (que dispõe sobre o acesso ao patrimônio genético e ao conhecimento tradicional associado) estabelece a seguinte definição de comunidade tradicional: "Grupo humano, incluindo os remanescentes de comunidades de quilombos, distinto por suas condições culturais, que se organiza, tradicionalmente, por gerações sucessivas e costumes próprios, e que conserva suas instituições sociais e econômicas". Melhor definição é trazida por Diegues e Arruda (apud Santilli, 2005, p. 132): "Grupos humanos diferenciados sob o ponto de vista cultural, que reproduzem historicamente seu modo de vida, de forma mais ou menos isolada, com base na cooperação social e relações próprias com a natureza. Tal noção refere-se tanto a povos indígenas quanto a segmentos da população nacional, que desenvolveram modos particulares de existência, adaptados a nichos ecológicos específicos". 
lização das técnicas de exegese propostas por Theodor Viewveg e Peter Häberle, no afã de dar reconhecimento ao direito costumeiro dessas comunidades, os quais se ligam à reprodução de suas tradições culturais, que, por sua vez, conectam-se decisivamente à realização de sua dignidade.

\section{PLURALISMO, DIGNIDADE HUMANA E O SIGNIFICADO DOS DIREITOS FUNDAMENTAIS}

O Estado Liberal de Direito, inaugurado com a pós-revolução francesa e a independência norte-americana, arrimava-se nas ideias iluministas de objetividade científica, individualismo e racionalismo, compreendendo a sociedade como algo homogêneo, estático e uniforme, sem espaço para a alteridade nem para o culturalmente diferente. Tudo o que era diverso dos padrões de uma sociedade "moderna" capitalista estaria fadado ao gradativo desaparecimento e à compulsiva absorção pela "sociedade envolvente". Neste contexto, o ser indígena era compreendido como uma condição provisória, destinada ao desaparecimento e à assimilação social² .

No entanto, com a derrocada do Estado de Direito, a progressiva ascensão do Estado Constitucional e a consequente positivação constitucional de um catálogo de direitos fundamentais, o princípio da dignidade humana foi alçado a valor fundamental do ordenamento jurídico, perpassando todos os aspectos do universo jurídico e social, realizando neles uma revolução sem precedentes. Materializar a dignidade passou a significar mais do que garantir a liberdade individual e a igualdade de condições perseguidas durante as revoluções liberais, significa possibilitar o exercício da diferença. Dignidade é poder ser diferente sem que isso acarrete a perda de direitos.

O direito à diferença e à diversidade construído na trajetória do Estado Constitucional surge como um baluarte na defesa dos interesses das minorias após séculos de marginalização social e esquecimento jurídico. Mulheres, homossexuais, índios, quilombolas e toda uma sorte de segmentos sociais diferenciados ganham voz e visibilidade no cenário social. Desnudou-se, então, a vasta formação étnica e cultural dos países latino-americanos, cujas sociedades são formadas por uma vasta gama de atores sociais, segmentos étnica e culturalmente diferenciados entre si e que precisam coexistir em harmonia debaixo de uma mesma Constituição e dentro de um mesmo Estado Nacional.

2 Vigorava no direito interno e internacional instrumentos normativos voltados à incorporação do indígena ao modo de vida "civilizado". Inclusive, o Estatuto do Índio, Lei n 6.001/1973, em vigor até hoje no ordenamento brasileiro, adota o paradigma assimilacionista de aculturação indígena, com "o propósito de preservar a sua cultura e integrá-los, progressiva e harmoniosamente, à comunhão nacional" (art. $1^{\circ}$ ). 
Daí ter Konrad Hesse ${ }^{3}$ afirmado que a Constituição não só possui a função de formar e manter a unidade política, organizando o Estado, como também ostenta uma função de integração política, harmonizando as diferentes opiniões, os anseios e as aspirações da sociedade plural, rompendo definitivamente com a compreensão homogênea da sociedade liberal. A Constituição pós-moderna é, pois, uma Carta essencialmente cosmopolita, refletindo a sociedade plural que conduz, articulando as diferentes necessidades e aspirações dos variados grupos de interesses que nela coexistem.

Esse mister de integração política desempenhado pela Constituição conduz à sua necessária abertura para abarcar tudo o que for fundamental para a concretização da dignidade humana dos diferentes segmentos coexistentes na sociedade que regula, absorvendo uma gama de direitos, que, pela sua condição elementar, elevaram-se ao status constitucional, sob o signo de direitos fundamentais, não só regras impositivas e cogentes, mas, sobretudo, princípios constitucionais cuja função integradora é notadamente sentida no campo da hermenêutica constitucional.

O papel do exegeta é extremamente relevante no contexto do pós-positivismo, visto que cabe a ele extrair o verdadeiro sentido e alcance da norma constitucional à luz dos valores relevantes à sociedade naquele dado momento histórico, contribuindo como verdadeiro coautor do processo de formação da norma jurídica. Daí que a Constituição de hoje necessita ser extremamente plástica, flexível, de forma a se amoldar aos valores contemporâneos da comunidade que regula, tendo a possibilidade de se renovar e de se reinventar de acordo com a evolução social, sem, contudo, implicar em uma reforma textual ${ }^{4}$ que acabaria por enfraquecer a sua força normativa.

Os direitos fundamentais nada mais são do que os valores relevantes a uma dada coletividade em um determinado momento de sua evolução histórica. São decisões políticas e escolhas relevantes (dimensão objetiva dos direitos fundamentais) tomadas por uma comunidade específica naquele determinado momento de seu desenvolvimento. Afirmamos, então, que cada catálogo de direitos varia no tempo e no espaço. É único. Por essa mesmíssima razão é que a Constituição pós-moderna necessita ser extremamente maleável, se flexionando conforme a progressiva evolução das

3 Constitución y Derecho Constitucional. In: BENDA, Ernst; MAIHOFER, Werner; VOGEL, Hans-Jochen; HESSE, Konrad; HEYDE, Wolfgang. Manual de derecho constitucional. 2. ed. Madri: Marcial, 2001. p. 3.

4 BASTOS, Celso Ribeiro; MEYER-PFLUG, Samantha. A interpretação como fator de desenvolvimento e atualização das normas constitucionais. In: SILVA, Virgílio Afonso da (Org.). Interpretação constitucional. São Paulo: Malheiros, 2005. p. 161 
necessidades sociais, absorvendo os valores que lhe são relevantes ${ }^{5}$, visto que o pilar de sua sustentação ergue-se a partir da dignidade da pessoa humana, valor que se renova a cada momento, não encontrando definição precisa e acabada.

Neste sentido, $\mathrm{Hesse}^{6}$ ainda afirma que os direitos fundamentais não possuem conteúdo uniforme, mas variável, dependendo de fatores extrajurídicos, como a cultura e a história de um povo, podendo um mesmo direito apresentar significados diferentes em constituições diferentes. Indo mais além, Carlos Frederico Marés ${ }^{7}$ leva em consideração que não existem direitos humanos universais, mas o direito universal de cada povo de construir o seu referencial de direitos humanos segundo as suas tradições, os seus usos e os seus costumes.

De fato, se o catálogo de direitos fundamentais significa os valores que são relevantes para uma determinada sociedade em determinado momento de sua evolução, em outra época, em um mesmo Estado, o rol de direitos apresentará significado diverso; da mesma forma que esse catálogo divergirá em seu significado do catálogo de outro Estado Nacional. Isto porque as necessidades sociais refletidas no elenco de direitos positivados na Constituição são cambiantes, transformando-se de acordo com as necessidades da época.

Disso decorre que também a compreensão do que seja a dignidade humana varia no tempo e no espaço, apresentando um significado amplíssimo, aberto às diversidades culturais e as variações sociais. Aliás, o alcance de seu conteúdo varia não só endemicamente (de acordo com a evolução histórica e correspondendo a maior ou menor heterogeneidade da comunidade), como varia a partir de um referencial externo de um Estado para outro.

A dignidade humana, como valor supremo a se irradiar por todo o ordenamento jurídico e a inspirar todo o rol de direitos com fins a garantir a todos um mínimo existencial em uma sociedade livre, justa e solidária, necessita apresentar um alto grau de adaptabilidade, de modo a abarcar as diferenças de contexto presentes na sociedade contemporânea. Sendo a

5 A Carta dos Estados Unidos da América mantém quase o mesmo texto desde a sua promulgação, em 1787. com algumas poucas emendas. É o melhor exemplo de Constituição rígida e simultaneamente plástica, dotando o intérprete de grande função reveladora da norma. Por meio da técnica da hermenêutica construtiva, os norte-americanos constroem o sentido das normas constitucionais de acordo com o momento histórico de sua evolução, dotando a Carta Maior de grande capacidade adaptativa.

6 Significado de los derechos fundamentales. In: BENDA, Ernst; MAIHOFER, Werner; VOGEL, Hans-Jochen; HESSE, Konrad; HEYDE, Wolfgang. Manual de derecho constitucional. 2. ed. Madrid: Marcial, 2001. p. 84-85.

$7 \quad 0$ renascer dos povos indígenas para o direito. Curitiba: Juruá, 2008. p. 83. 
Constituição um instrumento de integração política, harmonizando e equilibrando em seu cenário a diversidade de atores sociais, e sendo a dignidade o valor maior desta Carta, deve esta (a dignidade) também funcionar como ferramenta de integração social, uma força de inclusão, alcançando todos aqueles segmentos sociais conviventes em um mesmo Estado Nacional.

Por esta razão é que o significado do que seja a dignidade humana não pode se dar uniformemente, segundo os padrões ocidentais de uma sociedade global capitalista. As diferenças culturais devem ser absorvidas na compreensão do que é uma vida digna. Do contrário, estar-se-ía diante de um imperialismo disfarçado, o imperialismo da moral ocidental, sob padrões eurocêntricos e norte-americanos ${ }^{8}$. Afinal, até o status de Estado Constitucional é uma expressão cultural, e a sua imposição forçada é uma forma de dominação.

\subsection{Multiculturalismo e proteção à diversidade Cultural na AmÉrica Indígena}

Neste novo cenário político e social introduzido pelo Estado Constitucional se desenvolveu a ideia de multiculturalismo, consistindo no reconhecimento da diversidade de culturas no mundo que coexistem e se autoinfluenciam. No dizer de Boa Ventura de Souza Santos," "o termo 'multiculturalismo' generalizou-se como modo de designar diferenças culturais em um contexto transnacional e global"10. Compreendeu-se que os diversos povos que vivem em seus costumes próprios, reproduzindo as suas tradições milenares, se autorreconhecendo como segmento diferenciado da sociedade envolvente, merecem o direito à preservação de sua singularidade sociocultural $^{11}$, posto que sem ela perderiam a sua identidade enquanto povo, fator indissociável da preservação de sua dignidade humana.

Neste aspecto particular, por volta da década de 1980, em reconhecimento dos direitos das minorias étnicas à diferença, paulatinamente os países latino-americanos passaram a se autointitular sociedades pluriculturais

8 PIOVESAN, Flávia. Direitos humanos e o direito constitucional internacional. 11. ed. São Paulo: Saraiva, 2010. p. 156.

9 SANTOS, Boaventura de Sousa (Org.). Reconhecer para libertar: os caminhos do cosmopolitismo multicultural. Rio de Janeiro: Civilização Brasileira, 2003. p. 33.

10 Boa Ventura de Sousa Santos (op. cit., p. 28) descreve o multiculturalismo como o reconhecimento da pluralidade de culturas que existem no mundo; a coexistência de culturas diversas em um mesmo Estadonação; e a existência de uma multiplicidade de culturas que se influenciam dentro do mesmo Estado-nação e além dele.

11 Ao contrário do que possa parecer, o indígena ou o quilombola, por exemplo, não vão perder esta qualidade se vierem a conviver com outras formas culturais. Eventuais transformações oriundas do coexistir entre diferentes povos é o que caracteriza a reprodução cultural, sem que, com isso, o grupo perca a sua identidade, pois nenhuma cultura se mantém estática no tempo, todas se transformam em decorrência do contato com outras civilizações. 
e multiétnicas, inserindo em seus Textos Constitucionais direitos e garantias em prol da conservação da singularidade cultural dos povos indígenas que vivem, convivem e sobrevivem em seus territórios, resistindo bravamente contra o processo assimilacionista que teve início cinco séculos atrás.

Dessa forma, as constituições pós-modernas dos países americanos acabaram por romper com o modelo integracionista que vigorara até então, reconhecendo o índio não como uma categoria fadada à extinção e à gradativa incorporação ao modo de vida "civilizado", mas como um setor da sociedade que está aqui para ficar e que deseja preservar a sua singularidade sociocultural, merecendo todos os direitos conferidos às demais parcelas da sociedade, sem necessariamente perder a sua identidade histórica.

Assim, o multiculturalismo se incorpora às constituições pós-modernas, se elevando ao status de direito fundamental, posto que inarredável da preservação da dignidade humana dos povos indígenas e das demais comunidades que desenvolveram historicamente um estilo de vida tradicional, arrimado em usos e costumes próprios.

Neste viés, ganha especial realce a Convenção no 169 da Organização Internacional do Trabalho (OIT) - Convenção sobre povos indígenas e tribais em países independentes -, que trata, entre outros assuntos, da preservação da integridade étnica, cultural e religiosa dos índios, dos direitos originários sobre as terras que ocupam e sobre os recursos naturais nelas existentes, garantindo a igualdade de direitos entre indígenas e não indígenas, sobretudo no que tange à efetividade dos direitos humanos. A Convenção no 169 destaca-se no cenário internacional por sua inspiração multiétnica e pluricultural, superando, decisivamente, a antiga Convenção no 107 da OIT, que adotava o vetusto paradigma assimilacionista.

A ascensão do multiculturalismo no Brasil remonta ao período de redemocratização política vivenciado pelo País no final da década de 1980, marco inaugural do Neoconstitucionalismo brasileiro ${ }^{12}$ e de seus valores de sociedade plural. A derrocada do regime militar, o movimento das Diretas Já, a eleição de Tancredo Neves para a presidência da República e a instauração da Constituinte em 1987 geraram um forte clamor social por valores democráticos e proteção aos direitos fundamentais da pessoa humana, tão achincalhados pela Ditadura Militar. Este panorama acabou por dar voz às parcelas marginalizadas da sociedade, que viam a possibilidade de lutar por seus interesses, exigindo condições de igualdade e dignidade.

12 BARROSO, Luiz Roberto. Neoconstitucionalismo e constitucionalização do direito (o triunfo tardio do Direito Constitucional no Brasil). In: NETO, Cláudio Pereira de Souza; SARMENTO, Daniel. A constitucionalização do direito: fundamentos teóricos e aplicações específicas. Rio de Janeiro: Lumen Juris, 2007. p. 206. 
Assim, inovando na tradição constitucional brasileira, a Carta Política de 1988 rompeu com o paradigma assimilacionista, que, nas décadas anteriores, inclusive permeando as disposições do Estatuto do Índio ${ }^{13}$, estruturava o complexo de normas dedicado à proteção do indígena e que visava à gradativa superação de seu modo de vida "primitivo e obsoleto", que estaria fadado ao desaparecimento, pelo modo de vida "civilizado" ao qual o silvícola necessariamente iria, e "desejaria", se inserir.

A atual Constituição Federal (CF), com clara inspiração multicultural e pluriétnica, não só reconheceu aos índios o direito originário sobre as terras que tradicionalmente ocupam ${ }^{14}$, assegurando-lhes o usufruto exclusivo das riquezas nelas existentes, como estruturou um sólido sistema de reconhecimento e proteção à sua singularidade étnica, de forma a assegurar a reprodução física e cultural de suas comunidades (art. 231), garantindo- Ihes o direito de manter a sua organização social, os seus costumes, a sua religião, as suas línguas, as suas crenças e as suas tradições ${ }^{15}$.

Da mesma forma, totalmente imersa em valores socioambientais e multiculturais, inovou a Carta de 1988 ao conceder proteção às manifestações culturais dos afrodescendentes, incumbindo o Poder Público de proteger tais referências culturais, tendo em vista que constituem patrimônio cultural brasileiro (arts. 215, § 1, e 216). A Constituição ainda atribuiu aos remanescentes das comunidades quilombolas o direito de propriedade sobre os seus territórios ${ }^{16}$, conferindo, de forma inédita no ordenamento jurídico do País, proteção aos descendentes dos antigos escravos, deixados à margem das iniciativas governamentais desde a abolição da escravatura em 1888, quando os quilombos passaram da proibição a uma realidade simplesmente desconsiderada.

13 Observe que alguns dos dispositivos do Estatuto do Índio não foram recepcionados pela atual Carta da República, uma vez que se prendem ao paradigma integracionista de assimilação cultural, claramente ultrapassado não só pela nova Constituição brasileira, que protege a perpetuidade cultural dos silvícolas, quilombolas e demais populações formadoras do patrimônio cultural brasileiro, como também pelos valores pluralistas da pós-modernidade.

14 A expressão Direitos originários sobre as terras que habitam liga-se ao reconhecimento, pelo ordenamento jurídico brasileiro, da ocupação imemorial da terra pelos autóctones, quando em $1^{\circ}$ de abril de 16800 Alvará Régio os outorgou tal legitimidade. No entanto, só em 1934 uma Constituição brasileira iria tratar dos direitos dos povos indígenas, assegurando-Ihes a posse de suas terras. De lá para cá, a tendência das Constituições nacionais foi a manutenção do reconhecimento de que o direito da posse indígena sobre suas terras é congênito, restando o Alvará de 1680 ainda em vigor, posto que nunca fora revogado.

15 Comunidade indígena é aquela que se autoidentifica como segmento distinto da sociedade nacional, em virtude da consciência de sua singularidade étnica e continuidade histórico-cultural, com origem e descendência précolombiana. $\mathrm{O}$ índio, por sua vez, é aquele que se considera pertencente a esta comunidade, e é por ela reconhecido como seu membro. Por tanto, pelo critério da autoidentificação, é o sentimento de pertinência a uma dada comunidade que faz do índio um índio. É índio quem se sente índio, quem dá continuidade a identidade étnica por meio da reprodução físico-cultural.

16 Art. 68 do Ato das Disposições Constitucionais Transitórias (ADCT). 
A nova dogmática constitucional visa a preservar a diversidade cultural do País, reconhecendo que o Brasil é uma nação multicultural e pluriétnica, formada por uma riquíssima variedade de populações tradicionais que merecem ter o seu modo de vida secular e a sua cultura singular preservados, uma vez que contribuíram, e ainda contribuem, para a formação da identidade do povo brasileiro, consubstanciando nosso patrimônio cultural.

Desta feita, a CF dedicou todo um capítulo (arts. 215 e 216) à proteção das "manifestações das culturas populares, indígenas e afro-brasileiras, e das de outros grupos participantes do processo civilizatório nacional", considerando "patrimônio cultural brasileiro os bens de natureza material e imaterial", "portadores de referência à identidade, à ação, à memória dos diferentes grupos formadores da sociedade brasileira", determinando ao Poder Público a "defesa e valorização do patrimônio cultural brasileiro" e a "valorização da diversidade étnica e regional".

Assim, quilombolas, indígenas, seringueiros, babaçueiros, caiçaras, pescadores artesanais, ribeirinhos, castanheiros e toda uma sorte de populações que vivem um estilo de vida tradicional ganham espaço na tutela constitucional à diversidade cultural. Percebe-se, em verdade, que em nenhum dispositivo consta expressamente a opção constitucional pelo pluriculturalismo, como fez as constituições de outros países latinos ${ }^{17}$; entretanto, tal escolha resta clara e evidente em uma análise sistemática e holística da Carta Magna, que reconhece a importante participação de diferentes grupos étnicos e sociais no processo de formação da identidade cultural do povo brasileiro.

\section{A NOVA HERMEMÊUTICA CONSTITUCIONAL E OS DIREITOS INDÍGENAS}

Na conjuntura da sociedade plural e da Constituição plástica, ganhou especial destaque a atividade hermenêutica, mormente a interpretação constitucional desenvolvida pela jurisdição constitucional. Desde o caso Marbury x Madison ${ }^{18}$, enfrentado pela Suprema Corte norte-americana, em 1803, que a função de interpretação constitucional fora atribuída ao Poder

17 A Constituição paraguaia se declara uma Nação pluriétnica e bilíngue, reconhecendo o guaraní como língua oficial juntamente ao espanhol; da mesma forma, o Peru reconhece como oficiais, paralelamente ao castelhano, o aimara e o quechua, além de outras línguas aborígines; o México declara-se um país de composição pluricultural; bem como a Bolívia se intitula multiétnico e pluricultural. Já a Constituição colombiana, de maneira tímida, reconheceu a diversidade étnica da nação comprometendo-se a protegê-la, tal qual fez a brasileira e a nicaraguense.

180 então presidente da Suprema Corte norte-americana, John Marshall, inspirado nas ideias de Alexander Hamilton, em $O$ federalista, partiu da ideia de que, se cabia ao Judiciário a interpretação das leis, sendo a Constituição a lei suprema da Nação, competiria também aos juízes interpretá-la, dizendo o seu sentido e o seu alcance. 
Judiciário, a quem caberia a guarda da Carta Fundamental e o papel de dizer o seu sentido e alcance. De lá para cá grande foi a evolução no campo da exegese constitucional, principalmente durante a edificação do Estado Constitucional.

Com o advento do Neoconstitucionalismo e a consequente derrocada do Estado Liberal, as novidades introduzidas pelo fenômeno da pós-modernidade e toda aquela quebra de paradigmas que encerrou acabaram por transportar-se também para a esfera jurídica, onde operou uma verdadeira revolução, superando a ideologia do juspositivismo, cujos padrões mecanicistas de exatidão matemática haviam se coadunado com perfeição ao ideário liberal do Estado de Direito, mas insuficiente para acompanhar as inovações dinâmicas e pluralistas que o superariam.

A compreensão do direito como um sistema autopoiético, dissociado da realidade adjacente e suficiente por si mesmo para resolver os problemas cotidianos, cai por terra no Estado Constitucional, revelando que a norma jurídica significa algo mais do que o simples texto da lei, este que seria apenas "a cabeça do iceberg"19 nas palavras de Friedrich Müller, cabendo ao hermeneuta extrair de suas profundezas, aquela grande parte submersa, o seu verdadeiro sentido. Se na era do positivismo jurídico realidade e norma não se encontravam, no pós-positivismo que o sucede o intérprete constitucional é chamado a superar esse hiato entre a constituição formal e a constituição material, conectando de forma decisiva o direito à realidade que o envolve, onde interpretar a norma significa concretizá-la, e vice-versa, não havendo uma norma a ser interpretada se não houver um caso concreto a ser solucionado ${ }^{20}$.

Dessa nova hermenêutica, três métodos se fazem relevante para o desenlace de delicadas questões envolvendo os interesses indígenas: A teoria material da constituição e a sua abertura estruturante para absorver como fundamental direitos não inscritos no texto da Carta; as técnicas hermenêuticas lançadas por Thedor Viehweg, em sua Tópica e jurisprudência, e por Peter Häberle, em sua A sociedade aberta dos intérpretes da constituição.

\subsection{Direltos culturals à luz da teoria materlal da Constituição}

Já vimos que a preservação da singularidade cultural indígena e quilombola, bem como de outras comunidades tradicionais, consubstancia o direito fundamental a ser diferente. No entanto, se o direito à isonomia, à

19 BONAVIDES, Paulo. Curso de direito constitucional. 13. ed. São Paulo: Malheiros, 2003. p. 505.

20 Idem, p. 482. 
liberdade de crença e religiosa e de não discriminação integram o elenco constitucional dos direitos fundamentais inscritos no art. 5o, o direito à identidade cultural e a opção pluralista da nossa Carta não constam expressamente no texto normativo capital, o que poderia conduzir um intérprete desavisado a concluir pela não fundamentalidade do direito indígena e quilombola à continuidade étnico-cultural. Tais direitos, pois, devem ser compreendidos à luz da teoria material da Constituição, que outorga a uma norma o status da constitucionalidade não pela inscrição textual na Carta, mas pelo conteúdo notadamente ligado à dignidade humana.

Conforme mencionado alhures, uma importante característica do Neoconstitucionalismo reside na colocação do princípio da dignidade humana no epicentro da ordem constitucional, o qual, em virtude de seu caráter aberto, indeterminado e atrativo, acabou por proliferar um vasto rol de novos direitos que se elevaram o status da fundamentalidade ${ }^{21}$. Assim, os mais variados elementos relacionados à dignidade humana ganharam o plus da fundamentalidade, traduzindo-se em conteúdo constitucional, estando ou não expressamente previsto na Norma Maior, passando, então, a compor o bloco de materialidade constitucional.

Dessa forma, a teoria material da constituição significa o alargamento do conteúdo da Carta Fundamental, que passou a absorver ilimitadamente os valores e as tendências de sua época, correspondendo, assim, às necessidades mais relevantes dos diversos segmentos componentes da comunidade política que representa.

Deparamo-nos, então, com um sistema constitucional dilatado, expandido, composto por um bloco material de constitucionalidade, no qual se insere a Constituição formal. Dessa forma, o conteúdo constitucional vai se alargando, absorvendo, como uma espoja, os valores relevantes para a sociedade em cada etapa de seu desenvolvimento, cabendo ao hermeneuta redimensionar esse conteúdo ao sabor da evolução social. Tal fenômeno corresponde ao método construtivo de interpretação constitucional empregado pela Suprema Corte norte-americana, consistente na renovação do conteúdo constitucional sem reforma textual.

O alargamento material da Constituição ganha especial realce no contexto dos interesses indígenas e quilombolas, uma vez que importantes direitos destinados à tutela de sua dignidade provem de instrumentos internacionais. São direitos que, na maioria das vezes, não estão expressamente

21 CASTRO, Carlos Roberto Siqueira. A constituição aberta e os direitos fundamentais - Ensaios sobre o constitucionalismo pós-moderno e comunitário. Rio de Janeiro: Forense, 2005. p. 20. 
escritos na Constituição, muito embora, em face das chamadas cláusulas de abertura e do caráter amplíssimo do princípio da dignidade humana, compõem o bloco de materialidade constitucional dos países signatários do respectivo instrumento.

Com efeito, o art. 5으, $\S 2^{\circ}$, da Constituição Federal brasileira explicita que "os direitos e garantias expressos nesta Constituição não excluem outros decorrentes [...] dos tratados internacionais em que a República Federativa do Brasil seja parte". Busca a norma constitucional possibilitar a complementação do rol de direitos fundamentais previstos em seu texto normativo, reconhecendo que o catálogo de direitos fundamentais ali previsto não é taxativo nem exaustivo, merecendo ser ampliado pelas normas futuras que apresentem conteúdo de direitos fundamentais, privilegiando, assim, o primado da dignidade humana.

$\mathrm{O}$ art. $5^{\circ}, \S 2^{\circ}$, evidencia o caráter aberto da nossa Carta Constitucional, possibilitando uma ampliação ilimitada das garantias fundamentais outorgadas ao povo brasileiro, reconhecendo, inclusive, a legitimidade do direito internacional como instrumento apto a operar esse alargamento, mantendo uma porta constantemente aberta entre o direito doméstico e o internacional no que tange aos direitos fundamentais.

Daí que concluímos, não sem reconhecer a celeuma que envolve a matéria, pelo status de norma constitucional daqueles tratados e convenções internacionais ratificados pelo Brasil que versam sobre matéria de direitos humanos ${ }^{22}{ }_{2}^{23}$. O Texto Constitucional é claro e cristalino: "Os direitos e garantias expressos nesta Constituição não excluem outros decorrentes [...] dos tratados internacionais em que a República Federativa do Brasil seja parte", possibilitando o alargamento de seu catálogo fundamental a partir de normas internacionais atinentes aos direitos fundamentais da pessoa humana.

Construímos este raciocínio para chegarmos ao seguinte ponto: conforme já fartamente analisado nos capítulos anteriores, o direito à diferença e a proteção à singularidade cultural de índios, quilombolas e outras comunidades tradicionais é condição cine qua non da realização, em seu favor,

22 Adotam esta tese, muito embora minoritariamente, alguns Ministros do Supremo Tribunal, tais como Celso de Mello, Cesar Peluso, Ellen Grece e Eros Grau. Prevalece hoje na Suprema Corte o entendimento capitaneado pelo Ministro Gilmar Mendes, segundo o qual os tratados internacionais de direitos humanos possuem status supralegal, estando, pois, abaixo da Carta Constitucional.

23 Quanto ao $\S 3^{\circ}$ do art. $5^{\circ}$ que assinala que os tratados e as convenções internacionais sobre direitos humanos que forem aprovados segundo o quorum qualificado previsto para as emendas constitucionais serão a elas equiparados, cumpre observar que tal disposição gira em torno da positivação de tais normas internacionais no texto formal da Constituição, muito embora já componham o seu bloco material desde que ratificados pelo Brasil. Neste sentido, vide Flávia Piovesan (Op. cit., p. 72). 
da dignidade humana, uma conquista do multiculturalismo e das concepções de sociedade aberta e pluralismo alcançadas na pós-modernidade.

Dessa forma, insta reconhecer que os instrumentos internacionais destinados à tutela da identidade étnica e cultural dessas comunidades, desde que ratificados pelo País, elevam-se ao status de normas constitucionais, ainda que não estejam expressamente escritos em seu texto, em virtude do seu conteúdo de direito fundamental, compondo o nosso bloco de materialidade constitucional. Concluir de outra forma seria desprestigiar o citado dispositivo constitucional e a conquista que o mesmo representa, esvaziando o sentido da norma constitucional além de menoscabar o princípio da máxima efetividade das normas constitucionais.

\subsection{OS INTÉRPRETES DA DIGNIDADE INDÍGENA}

Sendo a Carta uma norma aberta e plástica, na qual se incorporam os valores sociais mais relevantes, e sendo a sociedade algo fluido e dinâmico, depreende-se que o conteúdo constitucional irá se alterando, seguindo o compasso da evolução social. A Carta, como vimos, se transforma espiritualmente sem, contudo, modificar o seu texto normativo. É neste aspecto que a atividade do hermeneuta ganha relevância no Estado Constitucional.

O juiz não é mais a "boca da Lei", como anunciou Montesquieu, a atividade interpretativa não corresponde mais aos moldes mecanicistas e objetivos do positivismo jurídico que imperou no constitucionalismo clássico liberal. O exegeta não está mais amarrado pura e simplesmente à letra fria da lei. A sociedade não é mais concebida como algo estático, cujas situações da vida se subsumiriam com perfeição aos códigos fechados. Cabe ao intérprete, após uma pré-compreensão da realidade que o cerca, extrair do texto normativo a verdadeira norma por traz do dispositivo interpretado, aproximando o direito da realidade social, compreendendo que o sentido e o alcance da norma variam conforme as flutuações sociais.

Maior responsabilidade é ainda atribuída ao hermeneuta em países cuja formação social é bastante heterogenia, tais como os latino-americanos de vasta formação étnica e cultural, especialmente o Brasil, com a sua rica diversidade de comunidades tradicionais. São índios, quilombolas, seringueiros, ribeirinhos, caiçaras, comunidades rurais, pescadores artesanais, populações urbanas, enfim, uma diversidade social que precisa ser administrada e equilibrada, a fim de que uma vida em dignidade seja assegurada a todos e que a coesão nacional se mantenha firme e estável. 
Daí porque ao intérprete cabe uma pré-compreensão da realidade nacional. É necessário absorver as diferentes nuances que a dignidade humana e os direitos fundamentais assumem para cada um desses segmentos sociais. O significado dos direitos elementares e a compreensão de uma vida digna não pode se limitar à concepção ocidental de uma sociedade global, esta corresponde a padrões culturais eurocentristas e norte-americanos difundidos por meio do modo de produção capitalista, não possuindo um conteúdo uniforme e universal, como pretendem os organismos internacionais. O direito a uma vida digna, segundo a própria compreensão de dignidade, esta sim é um direito universal, mas não o significado, o conteúdo desta dignidade. Universal é o direito de praticar a própria cultura, e não o conteúdo desta.

Os valores de relevância para um determinado povo divergem dos valores dos outros tantos povos que convivem no globo, a noção de uma "vida boa e feliz" vai se alterar em cada cultura e em cada momento histórico. Impor a uniformidade desta compreensão segundo os padrões ocidentais corresponde a uma dominação cultural, um imperialismo disfarçado sob o manto da dignidade humana, quando é esta a mais aviltada.

Neste sentido, Peter Häberle ${ }^{24}$ sustenta que precisa haver uma democratização da interpretação constitucional, pois quem vive a norma também a interpreta, sendo necessário integrar a realidade ao processo hermenêutico, o que somente seria possível com o alargamento do círculo de intérpretes da Constituição, tanto maior quanto mais pluralista for a sociedade. Para Häberle, a Constituição é o espelho da realidade, daí porque não poder deixar de fora do processo hermenêutico os viventes desta realidade.

Das lições de Peter Häberle extraímos a necessidade de congregar o direito à realidade social, lembrando que esta foi a finalidade intentada pelo Neoconstitucionalismo, quando surgiu para curar as mazelas provocadas pelo Estado Liberal ao separar drasticamente a dimensão jurídica da dimensão social. Não quer isso dizer que a interpretação oficial da jurisdição constitucional deva ser enfraquecida em vista da concorrência de uma infinidade de intérpretes constitucionais. O que extraímos das lições do autor é a necessidade de que a compreensão daqueles que vivem a norma seja incorporada nas decisões da Corte constitucional, que o real significado de uma vida em dignidade para povos étnica e culturalmente diferentes não

24 Hermenêutica constitucional - A sociedade aberta dos intérpretes da Constituição: a contribuição para a interpretação pluralista e "procedimental" da Constituição. Trad. Gilmar Ferreira Mendes. Porto Alegre: Sergio Antonio Fabris Editor, 1997. passim. 
seja eclipsado pela compreensão da sociedade envolvente, ou do próprio intérprete, do que seria uma vida digna.

Neste contexto, relevante se faz a técnica hermenêutica introduzida por Theodor Viehweg ${ }^{25}$, a tópica argumentativa que rompeu definitivamente com o método cartesiano do positivismo legalista, o qual concebia o direito como um sistema fechado e rígido. A tópica flexibilizou o direito que se transformou em um instrumento à disposição do intérprete que agora participa como coautor do processo de criação da norma. Segundo a tópica de Viehweg, para se solucionar um caso concreto, o intérprete deve possuir uma prévia compreensão dele, a partir da qual escolherá os topois, os nichos de informações que utilizará em sua argumentação jurídica pra se atingir uma decisão razoável.

Viehweg pressupõe que para um mesmo problema jurídico existem diversas possibilidades de solução, e não apenas uma solução correta, como pressupunham os juspositivistas, cabendo ao exegeta alcançar uma decisão satisfatória entre as possíveis, e para isso deve "pensar o problema", identificando no caso concreto os elementos dialógicos que culminarão em sua solução.

O método tópico de interpretação parece uma alternativa interessante na solução de questões indígenas ou envolvendo outros grupos étnica e culturalmente diferenciados, uma vez que possibilita ao hermeneuta maior maleabilidade na aplicação do Direito, já que pluraliza os métodos de revelação da norma, encontrando nas tradições culturais espaço para uma atuação criativa, reconhecendo o direito consuetudinário das comunidades tribais como mais um topoi, que, ao lado do direito interno e do internacional, além dos tantos outros topois acessíveis ao intérprete, lhes conduza a uma solução razoável do problema.

De fato, a tópica consiste em uma técnica de identificação de premissas aplicáveis ao caso concreto de difícil solução, já que nem todos os problemas da vida real seriam dedutíveis dos axiomas do ordenamento jurídico como pretendiam os juspositivistas. Existem casos para os quais o direito não apresenta solução, o que ocorre em razão da heterogeneidade social e da constante força dinâmica e transformadora da sociedade.

O método tópico de Theodor Viehweg, complementado pela democratização do processo hermenêutico da Constituição proposto por Peter

25 Em verdade, Theodor Vihweveg resgatou o método tópico idealizado por Aristóteles, dando-Ihe uma roupagem moderna. BUSTAMENAT, Thomas da Rosa. Tópica e argumentação jurídica. Revista de Informação Legislativa, Brasília, p. 158, jul./set. 2004. 
Häberle, parece o melhor caminho a ser seguido pelo Tribunal Constitucional quando em pauta delicadas questões envolvendo comunidades indígenas, uma vez que pode privilegiar o direito consuetudinário da comunidade, as suas tradições seculares e a sua compreensão do que significa uma vida em dignidade, conferindo efetividade às normas constitucionais que garantem aos índios o direito à perpetuidade de suas tradições milenares e à reprodução de sua cultura, suas crenças e sua religião.

Aqui abro um parêntese para ressaltar que não se pode generalizar a condição indígena, como se todo índio fosse igual ${ }^{26}$. Pelo contrário, cada etnia, cada povo, cada comunidade se desenvolveu de forma independente, as suas tradições variam tão intensamente entre si quanto as nossas divergem das deles. Cada etnia apresentará um direito consuetudinário, uma organização social, religiosa e cultural que lhe é peculiar, e cujos elementos devem ser levados em consideração na solução do caso concreto. Por esta razão se faz tão conveniente o uso da tópica como método de exegese para a solução de questões indígenas, e diante dela deve haver o reconhecimento do direito costumeiro.

\section{DIREITO CONSUETUDINÁRIO NO CONTEXTO DA JURISDIÇÃO CONSTITUCIONAL}

No atual modelo constitucional de Estado, ao qual nos encontramos inseridos, a ideia da coexistência em um mesmo território de sistemas jurídicos diversos é algo inexoravelmente rechaçado; no Estado contemporâneo prepondera a ideia de que o direito é único e onipresente, emanado de uma Carta Constitucional que paira intangível, inquestionável e soberana sobre todas as regras sociais de comportamento. Entretanto, a realidade dos diversos países sul-americanos e a sua variada rede de etnias indígenas, com regras de conduta social próprias, parece desmentir esta concepção.

A questão do reconhecimento pelo Estado da existência de um sistema jurídico entre os povos indígenas é polêmica antiga, que remonta à época das invasões europeias. A verdade é que, paralelamente às normas jurídicas que norteiam nosso ordenamento, existe uma infinidade de regras que organizam e mantêm coesas as diversas formações indígenas espalhadas não só no território brasileiro, mas por toda a América Latina ${ }^{27}$.

26 Neste sentido, confira o voto do Ministro Carlos Britto na demarcação da terra indígena Raposa Serra do Sol: “[...] 4. O significado do substantivo 'índios' na Constituição Federal. O substantivo 'índios' é usado pela Constituição Federal de 1988 por um modo invariavelmente plural, para exprimir a diferenciação dos aborígines por numerosas etnias. Propósito constitucional de retratar uma diversidade indígena tanto interétnica quanto intraétnica. Índios em processo de aculturação permanecem índios para o fim de proteção constitucional [...]".

27 Vide: FEIJÓ, Julianne Holder da Câmara Silva. 0 direito penal e o indígena: aspectos acerca da imputabilidade penal e da competência judiciária. Revista Jurídica In Verbis, Natal/RN, a. XIV, 25. ed., p. 127-139, jan./jun. 2009. 
A Convenção no 169 da OIT, em seu art. 9o, item 1, tem admitido que as comunidades índias apliquem as suas normas sociais de maneira subsidiária, desde que não se contraponham à ordem jurídica nacional, admitindo a realidade fática, muito embora não reconheça a existência de um efetivo direito. Também a Carta de Direitos do Cidadão, ratificada no México, recomenda ao Poder Judiciário dos Países signatários, entre eles o Brasil, a integração de mecanismos de solução de conflitos conforme aos direitos consuetudinários das populações indígenas, assegurando que o tratamento aos índios respeite a sua dignidade, o seu idioma, a sua organização social e as suas tradições culturais.

Por sua vez, o Estatuto do Índio, em seu art. 6º, dispõe que os usos, os costumes e as tradições das comunidades indígenas serão respeitados, inclusive quanto às relações de família, na ordem de sucessão, no regime de propriedade e nos atos ou negócios realizados entre índios, salvo se optarem pela aplicação do direito comum. Em verdade, a imposição de um sistema jurídico exógeno à comunidade indígena contrastaria com os preceitos constitucionais contidos no art. 231, que asseguram aos índios o direito à sua organização social, aos usos e aos costumes, uma vez que os obriga a seguir regras sociais diversas de seu modelo tradicional, desconfigurando a sua estrutura cultural ${ }^{28}$.

Neste contexto, interessante dispositivo é o art. 57 do Estatuto do Índio, que prevê a possibilidade de a própria comunidade tribal aplicar as san-

28 De fato, a jurisprudência do Tribunal Regional Federal da $1^{\text {a }}$ Região, como sempre avançada em questões envolvendo a condição indígena, reconhece a aplicação do direito costumeiro das tribos indígenas, conforme se observa no julgado que se segue:

"CIVIL - MANUTENÇÃO DE POSSE - ÁREA DE RESERVA INDÍGENA LOCALIZADA NOS MUNICÍPIOS DE NOVA AMÉRICA E RUBIATABA - ESTADO DE GOIÁS - CARRETÃO I - ALEGAÇÃO DE POVOAMENTO POR POSSEIROS - APELADO CASADO COM ÍNDIA TAPUIA DESDE 1974 - PROVA TESTEMUNHAL ACEITAÇÃO PACÍFICA NA RESERVA - PROCEDIMENTOS DE CONVIVÊNCIA REGULAR NÃO OBSERVADOS - OBSERVAÇÃO DAS SANÇÕES PREVISTAS NO ESTATUTO DO ÍNDIO - LEI N 6.001/1973

1. A Constituição Federal/1988, em seu art. 231, dispõe que 'são reconhecidos aos índios sua organização social, costumes, línguas, crenças e tradições, e os direitos originários sobre as terras que tradicionalmente ocupam, competindo à União demarcá-las, proteger e fazer respeitar todos os seus bens'.

2. O Estatuto do Índio (Lei no 6.001/1973), por sua vez, consigna que 'serão respeitados os usos, costumes e tradições das comunidades indígenas e seus efeitos, nas relações de família, na ordem de sucessão, no regime de propriedade e nos atos ou negócios realizados entre índios, salvo se optarem pela aplicação do direito comum' (art. $6^{\circ}$ ).

3. Ainda, em seu art. 57, dispõe que 'será tolerada a aplicação, pelos grupos tribais, de acordo com as instituições próprias, de sanções penais ou disciplinares contra os seus membros, desde que não revistam caráter cruel ou infamante, proibida em qualquer caso a pena de morte'.

4. A pretendida segregação do réu das terras indígenas não pode ser deferida em sede de ação possessória, e sim, mediante a aplicação, pelos grupos tribais, de acordo com as instituições próprias, de sanções penais ou disciplinares contra os seus membros, ou, através de procedimentos de natureza penal, mediante a tipificação de todas as suas condutas adversas aos costumes indígenas (grifamos).

5. Apelação da Funai não provida." (TRF 1a R., AC 2000.01.00.067444-1/GO, 5a T., Rel ${ }^{a}$ Des $^{\text {a }}$ Selene Maria de Almeida, 04.09.2009) 
ções que entender necessárias à disciplina e à punição de seus membros, desde que tais penas não sejam de morte nem possuam caráter infamante ou cruel. É o que a doutrina convencionou chamar de jurisdição indígena, posto que retira do Estado o jus puniendi, quanto aos delitos praticados entre os membros da comunidade tribal.

Agir de outro modo seria esvaziar o sentido da norma constitucional. Retirar dos indígenas a possibilidade de punir os seus próprios membros faltosos, conforme os seus usos e costumes, ou negar reconhecimento às relações por eles estabelecidas, segundo as suas tradições seculares, é desestruturar o seu sistema cultural, é intervir arbitrariamente nos hábitos da comunidade.

Exemplo da jurisdição indígena é o caso do índio Basílio, que matou outro indígena pertencente à sua tribo. Após cometer o crime, o acusado foi julgado pela própria comunidade tribal, recebendo a seguinte pena: cavar a cova e enterrar o corpo da vítima, ficando em degredo de sua comunidade e de sua família pelo tempo que a tribo entendesse suficiente. Submetido, o réu, ao júri popular, após o pronunciamento de uma antropóloga ${ }^{29}$, o representante do Ministério Público requereu a sua absolvição, por entender que o índio Basílio já havia cumprido a pena devida, imposta por sua comunidade, conforme os seus costumes e as suas tradições. Por unanimidade de votos, os jurados agraciaram o acusado com a exoneração da pena.

O problema é que o índio Basílio passou 14 anos preso, aguardando julgamento pelo Tribunal do Júri, quando poderia, desde logo, ter sido reconhecida a competência de seu povo para julgá-lo, nos moldes do art. 57 do Estatuto do Índio. Apesar da louvável atitude do Parquet, em reconhecer a idoneidade da tribo em punir os seus componentes, conforme os seus usos e as suas tradições, o fato é que os Tribunais superiores vêm se revelando intolerantes às regras internas dos grupos tribais, avocando para si a competência de crimes praticados entre índios dentro das reservas ${ }^{30}$, desvirtuando as normas constitucionais de proteção ao sistema cultural aborígine.

29 A antropóloga Alesandra Albert esclareceu que, segundo a tradição milenar da etnia Macuxi, a qual pertencia o réu, um índio que mata outro é submetido a um conselho, formado por indivíduos de reconhecida autoridade e de grande expressão política, escolhidos pela própria comunidade; sendo o réu um tuxaua, indivíduo que exerce uma função político-representativa, é costume da tribo que seja ele julgado perante seus companheiros tuxauas. Quem conta o caso do índio Basílio com riqueza de detalhes é Helder Girão Barreto (Direitos indígenas: vetores constitucionais. Curitiba: Juruá, 2008. p. 119).

30 Assim já decidiu o STF: "[...] Homicídio em que os acusados são índios. [...]. Irrelevância do fato ter ocorrido no interior de reserva indígena. Competência da Justiça Estadual. Ordem indeferida" (STF, HC 81827/MT, $2^{\mathrm{a}} \mathrm{T}$., Rel. Min. Maurício Corrêa, J. 28.05.2002, DJ 23.08.2002). 
Outro caso, relatado por Helder Girão Barreto" ${ }^{31}$, foi a "morte de um Canaimé", figura mítica ${ }^{32}$ bastante temida que integra a cultura de algumas etnias indígenas situadas no Estado de Roraima, de forte presença no imaginário dos Macuxi e Wapischanas. No fim da tarde, após o trabalho na roça, ao voltar para casa, dois irmãos indígenas passaram debaixo de uma árvore, quando pulou sobre eles o índio Mistalhin, que estava escondido. Os irmãos, assustados e pensando se tratar de um Canaimé, agrediram e mataram o outro indígena que os surpreendera. Pensavam estar se defendendo da entidade espiritual, uma legítima defesa putativa em nossa linguajem jurídica. Os irmãos indígenas acabaram sendo julgados e condenados segundo as leis dos não índios.

Como se vê, em algumas questões envolvendo interesses indígenas o sistema jurídico se vê diante de um impasse: proteger e garantir a singularidade cultural silvícola, tal qual determinou a Constituição Federal, o que exige o respeito as tradições e ao direito consuetudinário da tribo, ou assegurar a uniformidade e a soberania do direito federal por todo o território nacional, mesmo que isso implique desconsiderar as tradições aborígines. Pergunto então: Até onde vai a proteção conferida pela Constituição à perpetuidade das crenças e tradições culturais dos silvícolas? O que fazer quando os seus costumes chocam a nossa compreensão de dignidade?

Acredito que desconsiderar as tradições jurídicas dos aborígines, o seu direito consuetudinário, inexoravelmente ligado à perpetuidade de suas tradições culturais, significa fazer letra morta da Carta Constitucional, desconsiderando as suas normas explícitas de tutela à continuidade física e cultural dos índios, os seus modos de fazer e de viver, um acerto de contas pelos séculos de dominação cultural, um reconhecimento de que se resistiram tão bravamente ao processo assimilacionista é porque queriam continuar a ser o que sempre foram antes da chegada dos colonizadores: índios, vivendo como índios e não como "brancos".

Por outro lado, o reconhecimento do direito consuetudinário indígena traz à baila o problema de controlar tais situações para que a observância da norma constitucional não acabe por exculpar atrocidades contra os direitos humanos por quem, à guisa de invocar tradições culturais, pratica condutas sabidamente ilícitas. O Magistrado deve estar bastante atento e

\footnotetext{
BARRETO, Helder Girão. Op. cit., p. 117.

Segundo a lenda, o Canaimé seria uma entidade maligna da floresta que se veste com uma pele de jaguar para aterrorizar a comunidade durante a noite.
} 
munido de informações antropológicas confiáveis, antes de reconhecer o direito indígena como aplicável ao caso ${ }^{33}$.

Quanto aos costumes tribais que possam chocar a nossa compreensão de dignidade, argumento que muitos de nossos costumes também chocam a compreensão indígena do que seja dignidade e recupero o argumento utilizado alhures, de que a dignidade humana é um valor plástico, maleável, que se transforma de um grupo para outro, conforme as características da evolução histórica sofrida pela coletividade. Daí que a nossa noção de dignidade nunca se harmonizará com a noção das tantas comunidades silvícolas que se espalham pelo continente americano.

Por outro viés, estaremos diante de um verdadeiro conflito entre os direitos fundamentais: de um lado, os direitos fundamentais de exercício e preservação da própria cultura pelos índios, ligado a sua dignidade; por outro, a nossa compreensão de dignidade que se fere pela prática de alguns costumes tribais. Como é cediço, na solução de conflitos entre direitos fundamentais deve o intérprete lançar mão da proporcionalidade, a fim de solucionar o impasse sem afastar definitivamente um direito em razão do outro, mas sopesando o que deve preponderar naquela circunstância.

É necessário, pois, o reconhecimento da diferença, o respeito ao culturalmente diferente e a vontade de preservar a diversidade para que exista uma real materialização da dignidade humana, sem a maquiagem do conteúdo uniforme e universal dos direitos humanos concebido pela cultura nortista etnocêntrica.

\subsection{As FUnÇÕES ESTRUTURANTE E HERMENÊUTICA DA JURISDIÇÃO CONSTITUCIONAL EM QUESTÕES INDÍGENAS}

Entre as funções exercidas pelo Tribunal Constitucional, importa ao presente ensaio duas delas: a função estruturante e a função hermenêutica. Segundo nos ensina André Ramos Tavares ${ }^{34}{ }^{3} 35$, a função estruturante é aquela voltada para a manutenção do edifício jurídico-normativo segundo a lógica interna do sistema. No bojo da função estruturante se concentram as

33 Observe que não estamos a defender uma jurisdição indígena independente do ordenamento jurídico. Tal seria demasiado arriscado para a segurança e integridade nacional. Por esta razão é que defendemos o uso da tópica em questões envolvendo indígenas. Os casos deveriam passar pelo Judiciário, o que mudaria seria a postura dos Tribunais de aplicar nosso sistema jurídico a um universo social inteiramente diferente. Deverão eles reconhecer o arranjo jurídico de tribos que vivem em seus costumes e dar o processo por encerrado, como no caso do índio Basílio e como vem sendo feito pelo TRF da $1^{\text {a }}$ Região.

34 TAVARES, André Ramos. Teoria da justiça constitucional. São Paulo: Saraiva, 2005. passim.

35 Segundo o autor, o Tribunal Constitucional ostenta seis grandes funções, são elas: a função hermenêutica, a função estruturante, a função arbitral, a função legislativa, a função governativa e a função comunitarista. 
funções de controle da constitucionalidade das leis e dos atos normativos; a função cassatória, quando a Justiça constitucional funciona como receptáculo de recursos; e o controle da violação dos direitos fundamentais, que importa ao nosso estudo. Será a partir desta função que a Corte Constitucional se elevará à protetora dos direitos fundamentais, controlando qualquer violação, inclusive no que diz respeito aos direitos indígenas.

Já a função hermenêutica volta-se para a interpretação da Constituição (e não das leis, o que o Tribunal só realizará em sede de controle da constitucionalidade ou em sua função cassatória), quando o Tribunal Constitucional constrói a norma constitucional a partir do enunciado elaborado pelo legislador constituinte, sendo o responsável por dizer o sentido e o alcance da Carta Fundamental. É no exercício da função hermenêutica que a Corte Constitucional aplicará a teoria material da Constituição, construindo o bloco de constitucionalidade, bem como se utilizará das técnicas hermenêuticas adequadas ao encontro da verdadeira norma constitucional aplicável ao caso concreto. É no exercício desta função que poderá o Tribunal se utilizar da tópica e promover, ainda, a democratização do processo hermenêutico, tal qual propôs Viehweg e Häberle, respectivamente.

Sendo a Suprem Corte a guardiã primordial da Constituição brasileira, e sendo esta encimada pelo primado da dignidade humana, o qual conduz ao reconhecimento e à proteção da diversidade cultural do País, e que acabou provocando a elevação dos direitos indígenas ao status da fundamentalidade, acabamos por concluir que caberá a ele (o Supremo), Corte responsável pelo exercício da jurisdição constitucional brasileira, a repressão e o controle dos atos que atentem contra os direitos fundamentais dos autóctones, direitos estes que giram em torno da preservação de sua identidade cultural e da reprodução de seus modos tradicionais de fazer e de viver, restando à Suprema Corte o relevante papel de garante dos direitos indígenas, assegurando, na prática, a tutela constitucional de sua identidade sociocultural.

Com efeito, na oportunidade do julgamento da demarcação da terra indígena Raposa Serra do Sol em 2009, quando a Suprema Corte decidiu pela demarcação contínua da área, muito festejou-se os progressos da jurisprudência do egrégio Tribunal na defesa dos interesses indígenas. O reconhecimento de que a compreensão da terra para os indígenas ostenta um caráter de ancestralidade e resgate histórico das tradições e simbolismos da comunidade, assim como a compreensão pelo Tribunal de que o direito dos aborígines sobre as suas terras, sendo originário, prevalece sobre qualquer outro, inclusive sobre os pretensos direitos adquiridos de não índios, reafir- 
mando o caráter meramente declaratório da demarcação, revela a sensibilidade com que a Corte se debruçou sobre a questão ${ }^{36}$.

Não foi isso, contudo, o observado no caso da construção da hidrelétrica de Belo Monte, no Rio Xingu, Estado do Pará37, quando o Supremo Tribunal, em decisão monocrática da então Presidente Ministra Ellen Gracie, suspendeu em partes a decisão da $5^{a}$ Turma do Tribunal Regional Federal da 1르 Região, que havia declarado a invalidade do Decreto Legislativo $\mathrm{n}^{\circ}$ 788/2005, que autorizara o empreendimento sem consultar as comunidades impactadas, além de obstar o lbama de realizar tal oitiva sob o argumento de que o único responsável pela consulta às comunidades indígenas era o Congresso Nacional, segundo determinação constitucional ${ }^{38}$.

36 Vejamos parte do voto do Ministro Relator, Carlos Britto: “[...] 9. A demarcação de terras indígenas como capítulo avançado do constitucionalismo fraternal. Os arts. 231 e 232 da Constituição Federal são de finalidade nitidamente fraternal ou solidária, própria de uma quadra constitucional que se volta para a efetivação de um novo tipo de igualdade: a igualdade civil-moral de minorias, tendo em vista o proto-valor da integração comunitária. Era constitucional compensatória de desvantagens historicamente acumuladas, a se viabilizar por mecanismos oficiais de ações afirmativas. No caso, os índios a desfrutar de um espaço fundiário que thes assegure meios dignos de subsistência econômica para mais eficazmente poderem preservar sua identidade somática, linguística e cultural. Processo de uma aculturação que não se dilui no convívio com os não índios, pois a aculturação de que trata a Constituição não é perda de identidade étnica, mas somatório de mundividências. Uma soma, e não uma subtração. Ganho, e não perda [...] 11. O conteúdo positivo do ato de demarcação das terras indígenas. [...] 11.20 marco da tradicionalidade da ocupação. É preciso que esse estar coletivamente situado em certo espaço fundiário também ostente o caráter da perdurabilidade, no sentido anímico e psíquico de continuidade etnográfica. A tradicionalidade da posse nativa, no entanto, não se perde onde, ao tempo da promulgação da Lei Maior de 1988, a reocupação apenas não ocorreu por efeito de renitente esbulho por parte de não índios. Caso das 'fazendas' situadas na Terra Indígena Raposa Serra do Sol, cuja ocupação não arrefeceu nos índios sua capacidade de resistência e de afirmação da sua peculiar presença em todo o complexo geográfico da 'Raposa Serra do Sol'. [...] Terra indígena, no imaginário coletivo aborígine, não é um simples objeto de direito, mas ganha a dimensão de verdadeiro ente ou ser que resume em si toda ancestralidade, toda coetaneidade e toda posteridade de uma etnia. Donde a proibição constitucional de se remover os índios das terras por eles tradicionalmente ocupadas, assim como o reconhecimento do direito a uma posse permanente e usufruto exclusivo, [...] A Constituição de 1988 faz dos usos, costumes e tradições indígenas o engate lógico para a compreensão, entre outras, das semânticas da posse, da permanência, da habitação, da produção econômica e da reprodução física e cultural das etnias nativas. [...] 12. Direitos 'originários'. Os direitos dos índios sobre as terras que tradicionalmente ocupam foram constitucionalmente 'reconhecidos', e não simplesmente outorgados, com o que o ato de demarcação se orna de natureza declaratória, e não propriamente constitutiva. Ato declaratório de uma situação jurídica ativa preexistente. Essa a razão de a Carta Magna havê-los chamado de 'originários', a traduzir um direito mais antigo do que qualquer outro, de maneira a preponderar sobre pretensos direitos adquiridos, mesmo os materializados em escrituras públicas ou títulos de legitimação de posse em favor de não índios. Atos, estes, que a própria Constituição declarou como 'nulos e extintos' ( $\$ 6^{\circ}$ do art. 231 da CF). 13. O Modelo peculiarmente contínuo de demarcação das terras indígenas. 0 modelo de demarcação das terras indígenas é orientado pela ideia de continuidade. Modelo bem mais serviente da ideia cultural e econômica de abertura de horizontes do que de fechamento em 'bolsões', 'ilhas', 'blocos' ou 'clusters', a evitar que se dizime o espírito pela eliminação progressiva dos elementos de uma dada cultura (etnocídio)" (STF, PET 3388/RR, Tribunal Pleno).

37 Inicialmente denominada hidrelétrica de Kararaô, um grito de guerra na língua Kaiapó, a usina já correspondia a uma agressão às comunidade índias afetadas. Os conflitos envolvendo a usina se arrastam por duas décadas, os índios e populações locais já se pronunciaram por diversas vezes contrários ao empreendimento, mas o Governo Federal sistematicamente desconsidera a sua posição e insiste em tentar justificar a obra com o argumento da estratégica posição da região para o desenvolvimento da matriz energética brasileira.

38 Conferir o voto da Relatora, Desembargadora Selene Maria de Almeida: "[...] A primeira constatação que se tem da mera leitura do $\S 3^{\circ}$ do art. 231 das CF/1988 é a obrigatoriedade da consulta às comunidades indígenas afetadas. A hipótese não é de faculdade do Congresso Nacional. 0 constituinte ordenou que sejam 
Com efeito, o $\S 3^{\circ}$ do art. 231 da CF determina que, para o aproveitamento energético e dos potenciais hidrelétricos em terras indígenas, se faz necessária a prévia autorização do Congresso Nacional, ouvida as comunidades impactadas, exigindo a elaboração de lei complementar para a disposição do tema ( $\S 6^{\circ}$ do art. 231). No Brasil ainda não foi editada uma lei que regule o procedimento de consulta; no entanto, tendo a Convenção no 169 da OIT tratado do assunto, e sendo o Brasil o seu signatário, deverá o instrumento internacional ser chamado a incidir sobre o caso.

Entre as principais garantias previstas na Convenção no 169 da OIT em favor dos índios e das comunidades tribais, destaca-se o dever de realizar uma consulta prévia antes da tomada de qualquer decisão que possa Ihes afetar diretamente, seja uma medida legislativa ou executiva, seja a realização de um empreendimento econômico em suas terras ${ }^{39}$. O referido instrumento consagra, ainda, o direito dos povos interessados de serem consultados por meio de suas instituições representativas e mediante um procedimento apropriado (art. $6^{\circ}$, item 1, a).

A consulta consubstancia um instrumento de intermediação política entre os Estados independentes e as comunidades indígenas e tribais neles existentes, representando uma importante ferramenta de efetivação dos seus direitos fundamentais, garantindo o direito da comunidade de se autodeterminar, escolhendo o seu destino, resguardando a posse plena dos autóctones sobre as suas terras e sobre a exploração exclusiva dos recursos naturais existentes, bem como satisfaz o direito à preservação de sua cultura, suas crenças e suas tradições a partir do momento que propicia aos indígenas a escolha de querer, ou não, que o seu modo de vida seja devassado e misturado ao modus vivendi dos não índios. Portanto, é evidente a condição de direito fundamental atribuída à consulta prévia ${ }^{40}$.

'ouvidas as comunidades afetadas para que participem da definição dos projetos que afetarão suas terras e seu modus vivendi'. A consulta se faz diretamente à comunidade envolvida com o projeto de construção. Não há se falar em consulta à Funai a qual poderá emitir parecer sobre o projeto, mas não substitui a vontade dos indígenas. Portanto, a consulta é intuito personae. Essa problemática não está sendo discutida neste agravo, mas sua abordagem esclarece a intenção do legislador no tema do aproveitamento dos recursos naturais em terra indígena. Assim como a comunidade indígena não pode ser substituída por outrem na consulta, o Congresso Nacional também não pode delegar o ato. É o Congresso Nacional quem consulta, porque é ele que tem o poder de outorgar a obra. Quem tem o poder tem a responsabilidade pelos seus atos. [...]" (TRF $1^{\text {a }} \mathrm{R}$., AG 2006.01.00.017736-8/PA, 5a T., DJ 05.02.2007, p. 147).

39 Também o art. 32 da Declaração da ONU sobre povos indígenas consagra o direito de consulta antes da tomada de qualquer decisão que possa afetar comunidades índias. A referida Declaração foi fruto dos esforços do grupo de trabalho da ONU acerca da situação das populações indígenas de todo o mundo, criado em 1982 sob os cuidados de José Martinez Cobo, e cujo objetivo gravita em torno do desenvolvimento de ações internacionais para a proteção desses grupos vulneráveis.

40 Mais detalhes sobre a consulta política às comunidades indígenas vide: FEIJÓ, Julianne Holder da Câmara Silva. Exploração de petróleo em terras indígenas: à procura de um marco legal. Revista Direitos Culturais, Programa de Pós-Graduação em Direito - Mestrado da URI, Campus de Santo Ângelo/RS, v. 5, N. 9, p. 157-178, 
A realização pelo Congresso da consulta às comunidades se faz extremamente relevante, posto que será a Casa Legislativa quem decidirá pela realização ou não do empreendimento nas terras indígenas do Xingu, e não o Ibama. A edição prévia de um decreto legislativo pelo Congresso autorizando a construção da hidrelétrica sem a oitiva prévia das comunidades não supre a necessidade, sendo, em verdade, inconstitucional. Ao reconhecer a legitimidade do Decreto no 788/2005, o Supremo Tribunal negligenciou os direitos indígenas, analisando a questão de forma superficial, sem levar em conta os interesses e as reivindicações dos grupos autóctones ameaçados de ter as suas terras inundadas pelas águas da represa.

Não cumpriu a Corte com o seu papel de controle das violações dos direitos fundamentais, nem interpretou o dispositivo constitucional de forma a favorecer o interesse de grupos sociais fragilizados e desamparados ${ }^{41}$. Percebe-se que a jurisprudência da Corte ainda titubeia na afirmação dos direitos indígenas, sendo necessária ao Tribunal uma melhor compreensão do universo de necessidades índias que demandam proteção do ente público, mormente da Corte Constitucional, guardiã da Constituição e responsável pelo controle das violações dos direitos fundamentais.

\section{CONCLUSÕES}

Quando a índia Kayapó Tuíra levantou o seu facão em direção ao diretor da Eletronorte, José Antônio Muniz Lopes, nos idos 1989, quando da realização do I Encontro dos Povos Indígenas no Xingu, em Altamira no Pará, além da grande tensão provocada, o gesto da indígena deu concretude e visibilidade às reivindicações dos povos da floresta ameaçados pela construção da hidrelétrica de Kararaô, hoje rebatizada Belo Monte. Tuíra revelou aos "brancos civilizados" que os índios representam um obstáculo real à consolidação de seus cobiçosos empreendimentos econômicos em áreas de sensibilidade socioambiental, merecendo respeito e voz na tomada das decisões que lhes afetam diretamente, não tendo mais espaço a invisibilidade e a negligência com que vinham sendo tratados pelo Governo sempre que os seus interesses contrapunham-se aos gananciosos interesses do capital econômico. O episódio se repetiu em 2008, quando um grupo de indígenas

jul./dez. 2010. Disponível em: <http://srvapp2s.urisan.tche.br/seer/index.php/direitosculturais/issue/ view/23>. Acesso em: 2 jun. 2011.

41 Em protesto pela construção da hidrelétrica, realizou-se, em 1989, em Altamira no Pará, o I Encontro dos Povos Indígenas do Xingu, ou simplesmente encontro de Altamira, resultado da articulação de lideranças indígenas, movimentos ambientais e sociais contrários aos inúmeros empreendimentos econômicos realizados na Amazônia sem a devida participação dos indígenas e populações locais. Em 2008, realizou-se o II Encontro dos Povos Indígenas do Xingu, também em Altamira, no Pará, evento marcado pela agressão indígena a um engenheiro da Eletrobrás, e pela criação do Movimento "Xingu Vivo". 
agrediu a golpes de facão um engenheiro da Eletrobrás, no II Encontro dos Povos Indígenas do Xingu.

Passada mais uma década, a questão da hidrelétrica de Belo Monte se arrasta por entre os Tribunais do País em idas e vindas de decisões que ora reconhecem ora negam os direitos indígenas à terra e à reprodução cultural de suas tradições, em progressos e retrocessos cíclicos que atormentam os povos do Xingu com o fantasma da inundação de sua rica terra e afogamento da exuberante fauna e flora da região.

Há muito que no plano teórico a proteção à continuidade física e cultural dos autóctones fora reconhecida como urgente e relevante. Documentos internacionais e Constituições nacionais, entre as quais a brasileira, proclamam a necessidade de garantir a perpetuidade étnica e cultural dos indígenas, respeitando e protegendo a diversidade cultural do planeta. Tal fenômeno é fruto do Neoconstitucionalismo e do conceito de sociedade plural que encerra, responsável pela compreensão de que no mundo existe uma infinidade de grupos sociais culturalmente diferenciados que convivem e se autoinfluenciam em um processo constante e dinâmico, o multiculturalismo, que possibilitou a reformulação da compreensão de dignidade humana como um catalisador do direito à diferença e à diversidade cultural.

O problema é que, na prática, os direitos constitucionais dos silvícolas restam negligenciados. Sem a proteção do Estado e sem visibilidade no cenário social, os índios acabam entregues a própria sorte. Propõem-se, assim, que o Tribunal Constitucional do País, no desempenho de seu mister de proteção contra as violações dos direitos fundamentais, volte os seus olhos para a causa indígena, que enxergue a diversidade cultural do País e assegure a sua efetiva defesa, tal como garantiu a Constituição Federal, dando voz e vez a uma parcela já tão oprimida e marginalizada por cinco séculos de dominação.

\section{REFERÊNCIAS}

ALBUQUERQUE, Mario Pimentel. O órgão jurisdicional e a sua função. Estudos sobre a ideologia, aspectos críticos, e o controle do Poder Judiciário. São Paulo: Malheiros, 1997.

BARRETO, Helder Girão. Direitos indígenas: vetores constitucionais. Curitiba: Juruá, 2008.

BARROSO, Luiz Roberto. Neoconstitucionalismo e constitucionalização do direito (o triunfo tardio do Direito Constitucional no Brasil). In: NETO, Cláudio Pereira de Souza; SARMENTO, Daniel. A constitucionalização do direito: fundamentos teóricos e aplicações específicas. Rio de Janeiro: Lumen Juris, 2007. 
BASTOS, Celso Ribeiro; MEYER-PFLUG, Samantha. A interpretação como fator de desenvolvimento e atualização das normas constitucionais. In: SILVA, Virgílio Afonso da (Org.). Interpretação constitucional. São Paulo: Malheiros, 2005.

BERCOVICI, Gilberto. A constituição dirigente e a constitucionalização de tudo (ou nada). In: NETO, Cláudio Pereira de Souza; SARMENTO, Daniel. A constitucionalização do direito: fundamentos teóricos e aplicações específicas. Rio de Janeiro: Lumen Juris, 2007.

BONAVIDES, Paulo. Curso de direito constitucional. 13. ed. São Paulo: Malheiros, 2003.

- Do País constitucional ao País neocolonial - A derrubada da Constituição e a recolonização pelo golpe de Estado institucional. 3. ed. São Paulo: Malheiros, 2004.

Teoria do estado. 7. ed. São Paulo: Malheiros, 2008.

BOTELHO, Marcos César. Os povos indígenas e o direito a terra: o Supremo Tribunal Federal e o julgamento da demarcação da terra Raposa Serra do Sol. In: SIQUEIRA, Dirceu Pereira; BELINATI, Miguel (Coord.). Inclusão social e direitos fundamentais. São Paulo: Boreal, 2009.

BUSTAMENAT, Thomas da Rosa. Tópica e argumentação jurídica. Revista de Informação Legislativa, Brasília, p. 153-164, jul./set. 2004.

CASTRO, Carlos Roberto Siqueira. A constituição aberta e os direitos fundamentais - Ensaios sobre o constitucionalismo pós-moderno e comunitário. Rio de Janeiro: Forense, 2005.

FEIJÓ, Julianne Holder da Câmara Silva. O direito penal e o indígena: aspectos acerca da imputabilidade penal e da competência judiciária. Revista Jurídica In Verbis, Natal/RN, a. XIV, 25. ed., p. 127-139, jan./jun. 2009.

. Proteção à identidade cultural no contexto do Neoconstitucionalismo e da abertura constitucional. Artigo publicado nos Anais do Congresso Lusobrasileiro de direito do patrimônio cultural. Ouro Preto, mar. 2011.

. A casuística latino-americana de exploração de petróleo em terras indígenas: o desafio da concretização dos direitos humanos em prol das comunidades impactadas. Revista Direito E-nergia, Natal/RN, a. II, 2. ed., p. 1-20, jan./jun. 2010. ISSN 2175-6198. Disponível em: <http://www.ccsa.ufrn.br/ojs/index.php/DireitoE-nergia/article/viewFile/33/69>. Acesso em: 12 ago. 2010.

. Aspectos jurídicos acerca da exploração e produção de petróleo e gás natural em terras indígenas, 2009, 96 f. Monografia de Bacharelado em Direito pela Universidade Federal do Rio Grande do Norte. Natal, 2009.

Exploração de petróleo em terras indígenas: à procura de um marco legal.

Revista Direitos Culturais, Programa de Pós-Graduação em Direito - Mestrado da 
URI, Campus de Santo Ângelo/RS, v. 5, N. 9, p. 157-178, jul./dez. 2010. Disponível em: <http://srvapp2s.urisan.tche.br/seer/index.php/direitosculturais/issue/ view/23>. Acesso em: 2 jun. 2011.

GRIMM, Dieter. A função protetiva do Estado. In: NETO, Cláudio Pereira de Souza; SARMENTO, Daniel. A constitucionalização do direito: fundamentos teóricos e aplicações específicas. Rio de Janeiro: Lumen Juris, 2007.

HÄBERLE, Peter. Hermenêtica constitucional - A sociedade aberta dos intérpretes da Constituição: a contribuição para a interpretação pluralista e "procedimental" da Constituição. Trad. Gilmar Ferreira Mendes. Porto Alegre: Sergio Antonio Fabris Editor, 1997.

HESSE, Konrad. A força normativa da constituição. Trad. Gilmar Ferreira Mendes. Porto Alegre: Sergio Antonio Fabris Editor, 1991.

. Constitución y Derecho Constitucional. In: BENDA, Ernst; MAIHOFER, Werner; VOGEL, Hans-Jochen; HESSE, Konrad; HEYDE, Wolfgang. Manual de derecho constitucional. 2. ed. Madri: Marcial, 2001.

. Significado de los derechos fundamentales. In: BENDA, Ernst; MAIHOFER, Werner; VOGEL, Hans-Jochen; HESSE, Konrad; HEYDE, Wolfgang. Manual de derecho constitucional. 2. ed. Madrid: Marcial, 2001.

INSTITUTO SOCIOAMBIENTAL. Consulta livre, prévia e informada na Convenção no 169 da OIT. Disponível em: <http://www.socioambiental.org/inst/esp/consulta_previa>. Acesso em: 10 ago. 2010.

. Especial Belo Monte - A polêmica da usina de Belo Monte. Disponível em: <http://www.socioambiental.org/esp/bm/index.asp>. Acesso em: 10 nov. 2010.

MATHIAS, Fernando; YAMADA, Erika. Declaração da ONU sobre direitos dos povos indígenas. Disponível em: <http://pib.socioambiental.org/pt/c/direitos/internacional/declaracao-da-onu-sobre-direitos-dos-povos-indigenas $>$. Acesso em:

11 nov. 2010.

PEREIRA, Micheli. Direitos humanos: universalismo, indivisibilidade e democracia liberal x relativismo cultural, globalização e democracia "agonísta". Revista Direitos Culturais, Programa de Pós-Graduação em Direito - Mestrado da URI, Campus de Santo Ângelo/RS, v. 5, n. 9, p. 13-33, jul./dez. 2010. Disponível em: <http://srvapp2s.urisan.tche.br/seer/index.php/direitosculturais/issue/view/23>. Acesso em: 29 jun. 2011.

PIOVESAN, Flávia. Direitos humanos e o direito constitucional internacional. 11. ed. São Paulo: Saraiva, 2010.

QUEIROZ, Cristina. Direitos fundamentais sociais: questões interpretativas e limites de justiciabilidade. In: SILVA, Virgílio Afonso da (Org.). Interpretação constitucional. São Paulo: Malheiros, 2005. 
SANTILLI, Juliana. Socioambientalismo e novos direitos: proteção jurídica à diversidade biológica e cultural. São Paulo: Peirópolis, 2005.

SANTOS, Boaventura de Sousa (Org.). Reconhecer para libertar: os caminhos do cosmopolitismo multicultural. Rio de Janeiro: Civilização Brasileira, 2003. Disponível em: <http://books.google.com.br>. Acesso em: 16 maio 2011.

. Por uma concepção multicultural dos direitos humanos. Rio de Janeiro: Contexto Internacional, v. 23, jan./jun. 2001, p. 7-34. Disponível em: <http:// www.boaventuradesousasantos.pt/media/pdfs/Concepcao_multicultural_direitos_ humanos_Contextolnternacional01.PDF>. Acesso em: 22 maio 2011.

SEN, Amartya. Desenvolvimento como liberdade. Trad. Laura Teixeira Motta. São Paulo: Companhia das Letras, 2010.

SOUZA FILHO, Carlos Frederico Marés de. O renascer dos povos indígenas para o direito. Curitiba: Juruá, 2008.

STF - Supremo Tribunal Federal. Pesquisa de jurisprudência. Disponível em: $<$ http://www.stf.jus.br/portal/jurisprudencia/pesquisarJurisprudencia.asp $>$. Acesso em: 17 maio 2011.

TAVARES, André Ramos. Teoria da justiça constitucional. São Paulo: Saraiva, 2005.

TRIGUEIRO, André (Coord.). Meio ambiente no século 21: 21 especialistas falam da questão ambiental nas suas áreas de conhecimento. 5. ed. Campinas: Armazém do Ipê, 2008.

TRF 1ํㅡㄹ REGIÃO - Tribunal Regional Federal da 1ª Região. Pesquisa de jurisprudência. Disponível em: <http://www.trf1.gov.br/default.htm>. Acesso em: 13 ago. 2010.

VALE, André Rufino do. Aspectos do neoconstitucionalismo. Revista Brasileira de Direito Constitucional - RDBC, n. 9, p. 67-77, jan./jun. 2007.

VALE, André Rufino do; MENDES, Gilmar Ferreira. A influência do pensamento de Peter Häberle no STF. Consultor Jurídico, abr. 2010. Disponível em: <http://www. conjur.com.br/2009-abr-10/pensamento-peter-haberle-jurisprudencia-supremo-tribunal-federal?pagina=14>. Acesso em: 29 jun. 2011. 